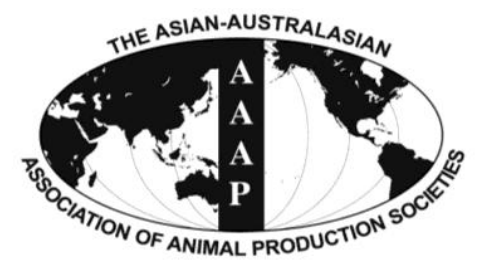

Asian-Aust. J. Anim. Sci.

Vol. 26, No. 4 : 552-557 April 2013

http://dx.doi.org/10.5713/ajas.2012.12557

www.ajas.info

pISSN 101 1-2367 elSSN 1976-5517

\title{
Immobilization of the Antarctic Bacillus sp. LX-1 $\alpha$-Galactosidase on Eudragit L-100 for the Production of a Functional Feed Additive
}

\author{
Jaekoo Lee ${ }^{\mathrm{a}}$, Inkyung Park ${ }^{\mathrm{a}}$ and Jaiesoon Cho* \\ Department of Animal Sciences and Environment, College of Animal Bioscience and Technology, \\ Konkuk University, 120 Neungdong-ro, Gwangjin-gu, Seoul 143-701, Korea
}

\begin{abstract}
Partially purified $\alpha$-galactosidase from Bacillus sp. LX-1 was non-covalently immobilized on a reversibly solubleinsoluble polymer, Eudragit L-100, and an immobilization efficiency of 0.93 was obtained. The optimum $\mathrm{pH}$ of the free and immobilized enzyme was 6.5 to 7.0 and 7.0, respectively, while there was no change in optimum temperature between the free and immobilized $\alpha$-galactosidase. The immobilized $\alpha$-galactosidase was reutilized six times without significant loss in activity. The immobilized enzyme showed good storage stability at $37^{\circ} \mathrm{C}$, retaining about $50 \%$ of its initial activity even after $18 \mathrm{~d}$ at this temperature, while the free enzyme was completely inactivated. The immobilization of $\alpha$-galactosidase from Bacillus sp. LX-1 on Eudragit L-100 may be a promising strategy for removal of $\alpha$-galacto-oligosaccharides such as raffinose and stachyose from soybean meal and other legume in feed industry. (Key Words: $\alpha$-Galactosidase, Bacillus, Eudragit L-100, Immobilization, $\alpha$-Galacto-oligosaccharides, Feed Industry)
\end{abstract}

\section{INTRODUCTION}

Soybean is a legume crop and a premier protein source of foods and feeds globally, owing to its well-balanced amino acid pattern (Thippeswamy and Mulimani, 2002; Stein et al., 2008). Nevertheless, the use of soybean-based foods or feeds has been occasionally restricted because they contain $\alpha$-galacto-oligosaccharides such as raffinose and stachyose, which act as anti-nutritive factors (De Lumen, 1992; Anderson and Wolf, 1995; Prashanth and Mulimani, 2005). Monogastric animals including human, swine, and poultry cannot synthesize sufficient $\alpha$-galactosidase (EC 3.2.1.22) in their gastrointestinal tracts (Karr-Lilienthal et al., 2005; Prashanth and Mulimani, 2005), which is an exoglycosidase catalyzing the hydrolysis of terminal nonreducing $\alpha-1,6-$ linked galactosyl residues from a wide range of galacto-oligosaccharides and polysaccharides (Naumoff, 2004). Thus, the $\alpha$-galacto-oligosaccharides pass into the large intestine, where the resident microbita ferment them into carbon dioxide, hydrogen, and methane, which lead to flatulence and gastrointestinal disorder (Steggerda et al.,

\footnotetext{
* Corresponding Author: Jaiesoon Cho. Tel: +82-2-450-3375, Fax: +82-2-455-1044, E-mail: chojs70@konkuk.ac.kr

${ }^{a}$ These authors equally contributed to this work.

Submitted Oct. 9, 2012; Accepted Dec. 2, 2012; Revised Dec. 11, 2012
}

1966; Prashanth and Mulimani, 2005). Accordingly, degradation of the oligosaccharides from the soybean-based products by $\alpha$-galactosidase could be an efficacious tool to solve the nutritional problem (Ghazi et al., 2003; Gote et al., 2004; Falkoski et al., 2009).

Considerable attention has been paid to immobilized enzymes, because of their favorable features such as reusability, stability, and separation of the enzymes from products, compared to free counterparts (Falkoski et al., 2009). Particularly, concerning animal nutrition and feed science, the immobilization technique has been applied in developing a kit for measuring in vitro amino acid digestibility of soybean meal, which could be correlated to poultry true amino acid digestibility (Schasteen et al., 2007) and in preparing a forage additive (Monica et al., 2008). Up to now, several matrices including polyacrylamide, alginate, chitin, silica gel, Amberlite IRA-938, and Sepabeads EC have been used as support materials for preparing immobilized $\alpha$-galactosidases (Onal and Telefoncu, 2003a,b; Prashanth and Mulimani, 2005; Falkoski et al., 2009; Bayraktar et al., 2011). Additionally, there is much interest in Eudragit L-100 (a copolymer of methacrylic acid and methylmethacrylate) which was utilized as a reversibly soluble and insoluble immobilization matrix for immobilization of the widely used technological enzymes 
such as xylanase (Sardar et al., 2000; Gaur et al., 2005), cellulase (Zhang et al., 2010), and amylase (Cong et al., 1995), as well as a pH-dependent enteric coating polymer for the efficacious colon-specific drug delivery system (Venkatesh et al., 2009).

To the best of our knowledge, the present study is the first report on the immobilization of $\alpha$-galactosidase on Eudragit L-100. The $\alpha$-galactosidase was derived from an Antarctic bacterial isolate, Bacillus LX-1 as previously described (Lee et al., 2012).

\section{MATERIALS AND METHODS}

\section{Reagents}

Eudragit L-100, which is a copolymer of methacrylic acid and methylmethacrylate at a ratio of 1:1, was a product of Rohm Pharma, Weiterstadt, Germany. The substrate, $p$ nitrophenyl- $\alpha$-D-galactopyranoside ( $p$ NPG) was purchased from Sigma-Aldrich (St. Louis, MO, USA). All other chemicals used were of analytical grade.

\section{Preparation of free $\alpha$-galactosidase}

Bacillus sp. LX-1 was cultivated in $25 \mathrm{ml}$ of LuriaBertani (LB) medium supplemented by containing $1 \%$ galactose in an Erlenmeyer flask of $250 \mathrm{ml}$ capacity for 24 $\mathrm{h}$ at $28^{\circ} \mathrm{C}$. Then, $1 \mathrm{~L}$ of the same medium in two Erlenmeyer flasks of 2 L capacity was aseptically inoculated with $1 \%$ seed culture broth and aerobically grown with vigorous shaking $(220 \mathrm{rpm})$ for $48 \mathrm{~h}$ at $28^{\circ} \mathrm{C}$. The culture medium containing secreted $\alpha$-galactosidase was centrifuged $\left(10,000 \times \mathrm{g} ; 20 \mathrm{~min} ; 4^{\circ} \mathrm{C}\right)$ to remove cell, and then protein in the supernatant was precipitated with ammonium sulfate (75\% saturation). The pellet was dissolved in $25 \mathrm{mM}$ Tris- $\mathrm{HCl}(\mathrm{pH} 8.0)$ and dialyzed overnight against $25 \mathrm{mM}$ Tris- $\mathrm{HCl}\left(\mathrm{pH} \mathrm{7.4)}\right.$ at $4{ }^{\circ} \mathrm{C}$. The dialyzed solution was used as the free enzyme throughout this work.

\section{Immobilization of $\alpha$-galactosidase on Eudragit L-100}

$2 \%$ Eudragit L-100 solution was prepared as previously described (Roy et al., 2003). The free enzyme (0.1 to $2 \mathrm{ml}$ ) was added to $0.75 \mathrm{ml}$ of the Eudragit L-100 solution and the final volume was made up to $5 \mathrm{ml}$ with $50 \mathrm{mM}$ sodium phosphate ( $\mathrm{pH}$ 7.0). After $1 \mathrm{~h}$ incubation at room temperature, polymer was precipitated by lowering $\mathrm{pH}$ to 4.0 with $3 \mathrm{M}$ acetic acid. After $20 \mathrm{~min}$, the suspension was spun down by centrifugation $(12,000 \times \mathrm{g}, 20 \mathrm{~min})$. The precipitate was washed with $4 \mathrm{ml}$ of $10 \mathrm{mM}$ sodium acetate (pH 4.0) until no enzyme activity was detected in the washings. Finally, the pellet so formed was suspended in 5 $\mathrm{ml}$ of $50 \mathrm{mM}$ sodium phosphate $(\mathrm{pH} \mathrm{7.0)}$ and used as the immobilized enzyme preparation.

\section{Enzyme activity assay}

The $\alpha$-galactosidase activity was determined by the amount of $p$-nitrophenol released from the $p$ NPG. The reaction mixture $(1 \mathrm{ml})$ containing $0.1 \mathrm{ml}$ of diluted soluble enzyme (free or immobilized), $0.8 \mathrm{ml}$ of $50 \mathrm{mM}$ sodium phosphate (pH 7.0 ) and $0.1 \mathrm{ml}$ of $10 \mathrm{mM}$ pNPG in $50 \mathrm{mM}$ sodium phosphate $(\mathrm{pH} 7.0)$ was incubated at $40^{\circ} \mathrm{C}$ for 15 min. The reaction was terminated by adding $1 \mathrm{ml}$ of $1 \mathrm{M}$ $\mathrm{Na}_{2} \mathrm{CO}_{3}$. The absorbance was measured at $405 \mathrm{~nm}$. One unit (U) of enzyme activity was defined as the amount of enzyme required to liberate $1 \mu \mathrm{mol}$ of $p$-nitrophenol per minute under the assay conditions.

\section{Reusability of the immobilized enzyme}

The immobilized $\alpha$-galactosidase was used for repeated cycles to check its reusability. The preparation was incubated at $40^{\circ} \mathrm{C}$ with $1 \mathrm{mM} p \mathrm{NPG}$ in $50 \mathrm{mM}$ sodium phosphate $(\mathrm{pH}$ 7.0) for 15 min. After each cycle of hydrolysis, the $\mathrm{pH}$ of the supernatant was lowered to 4.0 by adding $0.2 \mathrm{ml}$ of $3 \mathrm{M}$ acetic acid when the immobilized enzyme was precipitated. This was collected by centrifugation $(12,000 \times \mathrm{g}, 30 \mathrm{~min})$ and the amount of released $p$-nitrophenol in supernatant estimated according to the analytical method described above. For running the second cycle, the immobilized enzyme was redissolved in 5 $\mathrm{ml}$ of $50 \mathrm{mM}$ sodium phosphate $(\mathrm{pH} 7.0)$ and added to the $p$ NPG and processed the same way as before.

\section{Determination of pH optimum}

The effects of optimum $\mathrm{pH}$ on the free and immobilized LX-1 $\alpha$-galactosidase were investigated by assaying both preparations in the $\mathrm{pH}$ range of 3 to $8.5(50 \mathrm{mM}$ glycine$\mathrm{HCl}(\mathrm{pH} 3) ; 50 \mathrm{mM}$ sodium acetate $(\mathrm{pH} 4$ to 5.5$) ; 50 \mathrm{mM}$ sodium phosphate (pH 6 to 7 ) and $50 \mathrm{mM}$ Tris- $\mathrm{HCl}(\mathrm{pH} 7.4$ to 8.5$)$ ) at $30^{\circ} \mathrm{C}$.

\section{Determination of optimum temperature}

The effects of optimum temperature on the free and immobilized enzyme were determined by assaying their activities at different temperatures $\left(0\right.$ to $\left.80^{\circ} \mathrm{C}\right)$ in $50 \mathrm{mM}$ sodium phosphate ( $\mathrm{pH} 7.0)$.

\section{Determination of shelf storage stability}

For testing the shelf storage stability of enzymes, both free and immobilized LX-1 $\alpha$-galactosidase were stored at $37^{\circ} \mathrm{C}$ for $18 \mathrm{~d}$. Then the remaining activity of the enzymes was measured under the standard assay conditions.

\section{RESULTS AND DISCUSSION}

\section{Immobilization of LX-1 $\alpha$-galactosidase}

LX-1 $\alpha$-galactosidase was immobilized on the smart polymer, Eudragit L-100, which is a relatively cheap, easily 
available, non-toxic, and water soluble support, and which binds non-covalently to proteins (Gaur et al., 2005). The optimal immobilization efficiency of 0.93 was achieved at $0.77 \mathrm{U}$ of enzyme load and, beyond the amount of enzyme, the immobilization efficiency tended to decrease (Figure 1). Figure 2 depicted the activity staining of the immobilized enzyme. The decrease of immobilization efficiency with larger enzyme load is generally caused by overcrowding of the enzyme on the Eudragit surface (Sardar et al., 2000; Roy et al., 2003). Meanwhile, only 0.55 of the optimal immobilization efficiency was observed when $\alpha$ galactosidase from Penicillium griseoroseum was immobilized onto modified silica gel using glutaldehyde linkages (Falkoski et al., 2009). Thus, the immobilization yield of LX-1 $\alpha$-galactosidase seemed to be acceptable.

\section{Reusability of immobilized enzyme}

As an immobilization matrix, the merit of Eudragit L100 is its solubility during catalysis with its insolubility below $\mathrm{pH} 4.0$, enabling catalyst recovery and separation of the soluble reaction products by lowering the $\mathrm{pH}$ (Roy et al., 2003; Gaur et al., 2005). Reusability of an immobilized enzyme is of great importance for economical use of the enzyme in repeated batch or continuous processes (Bayraktar et al., 2011). As shown in Figure 3, the immobilized LX-1 $\alpha$-galactosidase could be recycled for six times without significant loss in activity, despite the fact that the enzyme was recovered by lowering the $\mathrm{pH}$ to 4.0 after each cycle. Such acidic process for enzyme recovery, which has routinely used in other enzymes immobilized on Eudragit matrices (Gaur et al., 2005; Silva et al., 2006; Zhang et al., 2010) did not have any negative effect on the LX-1 $\alpha$-galactosidase activity. This may be somewhat associated with previous report that immobilization of

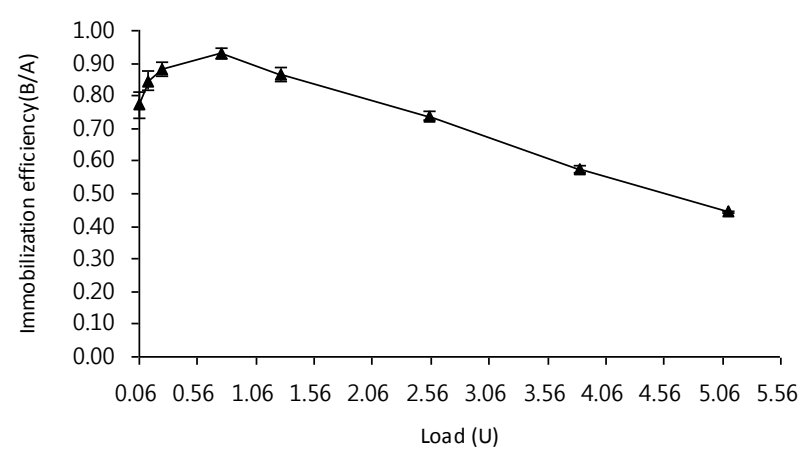

Figure 1. Immobilization of LX-1 $\alpha$-galactosidase on Eudragit L100. "A" represents the amount of enzyme theoretically bound to the matrix. This is calculated by subtracting the unbound activity in the supernatant from initially added enzyme. "B" represents the expressed activity of the particular immobilized preparation, measured after incubating the immobilized enzyme with the substrate. Data were expressed as mean \pm standard error from three experiments.

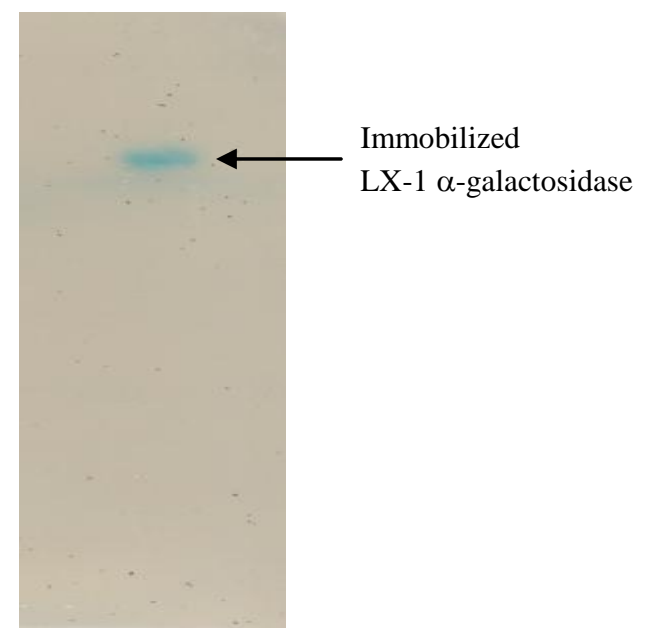

Figure 2. Zymogram analysis of $\alpha$-galactosidase activity in the immobilized enzyme.

Aspergillus niger xylanase on Eudragit L-100 has led to stabilization of the enzyme toward alternate exposure to $\mathrm{pH}$ 4.0 and pH 5.5 (Sardar et al., 2000).

\section{Effect of pH on activity of free and immobilized enzyme}

As shown in Figure 4, the optimum $\mathrm{pH}$ values for the free and immobilized LX-1 $\alpha$-galactosidase were 6.5 to 7.0 and 7.0, respectively. Although the $\mathrm{pH}$ profile change in immobilized enzymes was very common (Thippeswamy and Mulimani, 2002; Bora et al., 2005; Sanjay and Sugunan, 2005), immobilization of enzymes on the reversibly soluble-insoluble polymers such as Eudragit L-100 and Eudragit S-100 had frequently marginal effect on the optimal pH activities (Ai et al., 2005). For instance, there were no and slight changes in the optimum $\mathrm{pH}$ values for Aspergillus niger and Scytalidium thermophilum xylanase immobilized on Eudragit L-100, respectively (Sardar et al., 2000; Gaur et al., 2005). In addition, the optimum $\mathrm{pH}$ value of tomato $\alpha$-galactosidase immobilized on galactosecontaining polymeric beads and the free enzyme was identically pH 4.0 (Okutucu et al., 2010).

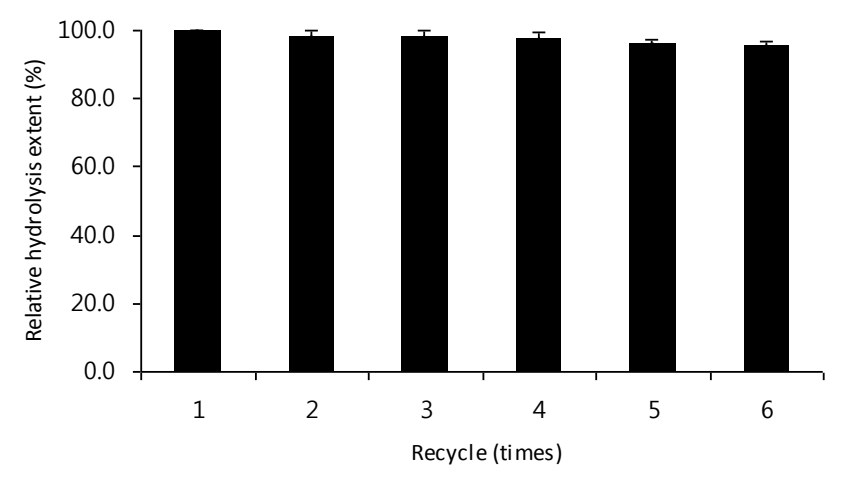

Figure 3. Reusability of the immobilized LX-1 $\alpha$-galactosidase. Data were expressed as mean \pm standard error from three experiments. 


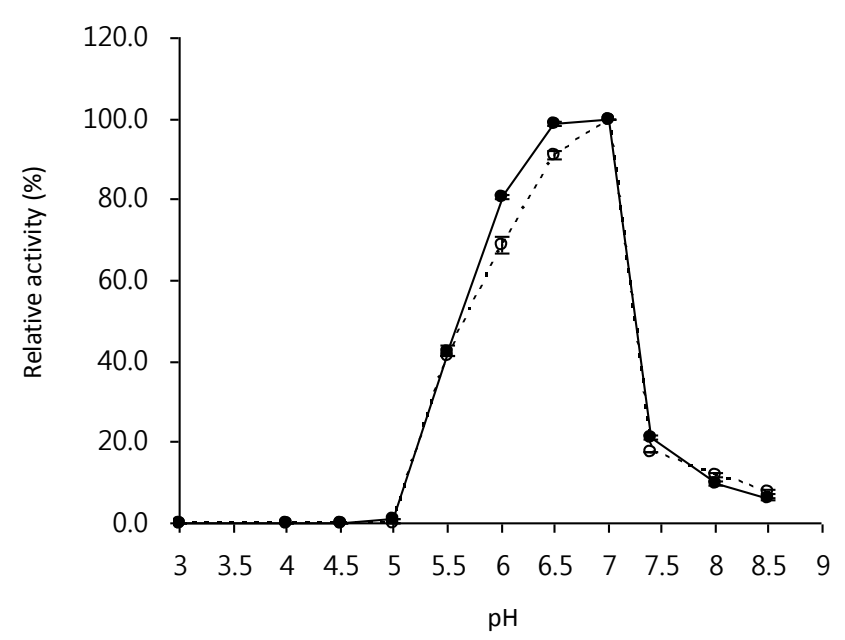

Figure 4. Effect of $\mathrm{pH}$ on LX-1 $\alpha$-galactosidase activity. Data were expressed as mean \pm standard error from three experiments. Immobilized enzyme (open circle with dotted line); free enzyme (closed circle with solid line).

Effect of temperature on activity of free and immobilized enzyme

The optimum temperature for the free and immobilized LX-1 $\alpha$-galactosidase was $40^{\circ} \mathrm{C}$ (Figure 5). Immobilization had no influence on the optimum temperature of the enzyme, which was also observed in a commercial protease, Esperase, immobilized on Eudragit S-100 (Silva et al., 2006), the Penicillium griseoroseum $\alpha$-galactosidase immobilized on silica gel (Falkoski et al., 2009) and the tomato $\alpha$-galactosidase immobilized on galactosecontaining polymeric beads (Okutucu et al., 2010). However, the optimum temperature of the Streptomyces olivaceoviridis E-86 xylanase immobilized on Eudragit S100 moved from $60^{\circ} \mathrm{C}$ (the optimum temperature of free enzyme) to $65^{\circ} \mathrm{C}$ (Ai et al., 2005).

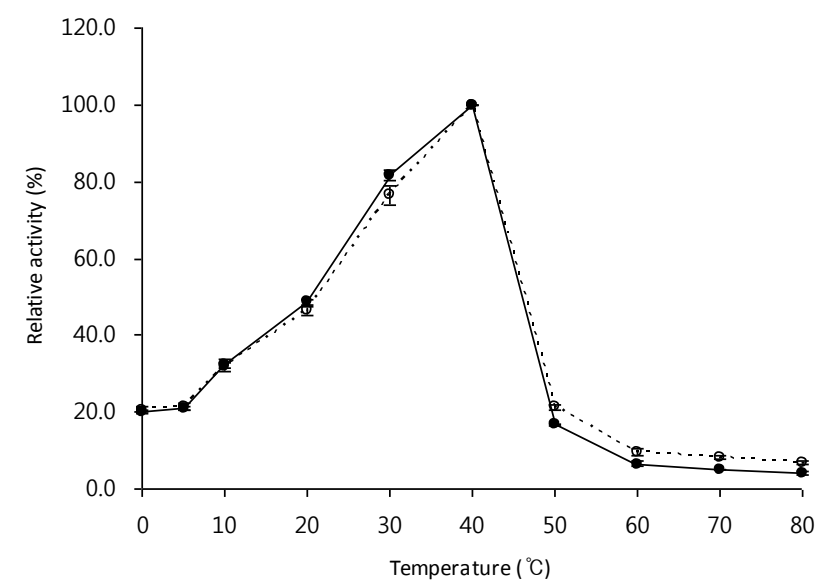

Figure 5. Effect of temperature on LX-1 $\alpha$-galactosidase activity. Data were expressed as mean \pm standard error from three experiments. Immobilized enzyme (open circle with dotted line); free enzyme (closed circle with solid line).

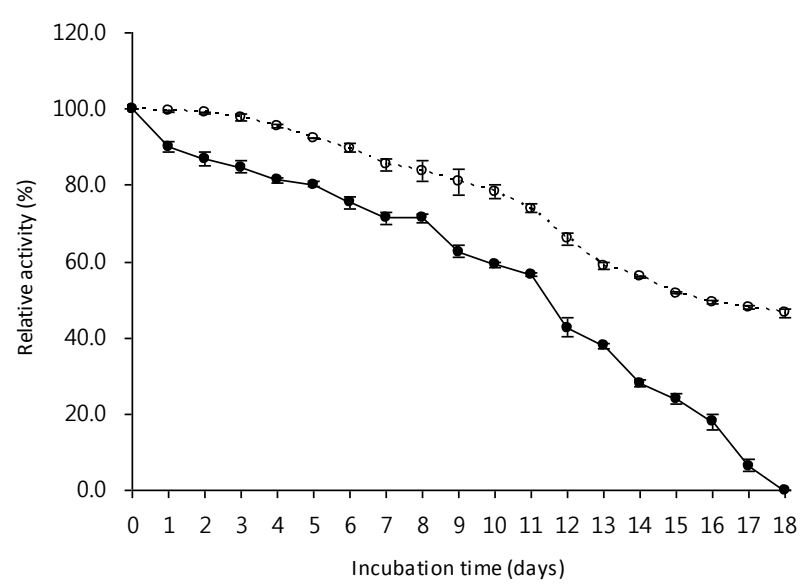

Figure 6. Storage stability of free and immobilized LX-1 $\alpha$ galactosidase at $37^{\circ} \mathrm{C}$. Data were expressed as mean \pm standard error from three experiments. Immobilized enzyme (open circle with dotted line); free enzyme (closed circle with solid line).

\section{Storage shelf stability of free and immobilized enzymes}

In general, an enzyme in solution is not stable during storage and the activity is gradually decreased over time (Bayraktar et al., 2011). From a practical point of view, it is an important criterion that an enzyme designed for use in animal feed should survive storage at ambient temperature (Francesch and Perez-Vendrell, 1997; Sulabo et al., 2011). As shown in Figure 6, the storage stability at $37^{\circ} \mathrm{C}$ was greatly improved by immobilization. The immobilized LX$1 \alpha$-galactosidase retained about $50 \%$ of its initial activity even after $18 \mathrm{~d}$ at this temperature, while the free enzyme was completely inactivated. The improved stability of immobilized enzymes may be associated with the prevention of autolysis (Sharma et al., 2003). In addition, the storage stability of immobilized enzymes varies depending on the applied immobilization method and storage conditions (Onal and Telefoncu, 2003b; Celem and Onal, 2009; Okutucu et al., 2010).

\section{CONCLUSIONS}

Nowadays, advanced feed production can rely on biotechnological approaches. The immobilization of $\alpha$ galactosidase from Bacillus sp. LX-1 on Eudragit L-100 may be a promising strategy for removal of $\alpha$-galactooligosaccharides such as raffinose and stachyose from soybean meal and other legume in feed industry, which enables to increase the available energy and feed efficiency (Suarez et al., 1999; Vila and Mascarell, 1999), due to its relatively durable enzyme activity and good storage stability.

\section{ACKNOWLEDGEMENTS}

This research was supported by Bio-industry Technology Development Program, Ministry for Food, 
Agriculture, Forestry and Fisheries, Korea.

\section{REFERENCES}

Ai, Z., Z. Jiang, L. Li, W. Deng, I. Kusakabe and H. Li. 2005. Immobilization of Streptomyces olivaceoviridis E-86 xylanase on Eudragit S-100 for xylo-oligosaccharide production. Process Biochem. 40:2707-2714.

Anderson, R. L. and W. J. Wolf. 1995. Compositional changes in trypsin inhibitors, phytic acid, saponins and isoflavones related to soybean processing. J. Nutr. 125:581S-588S.

Bayraktar, H., M. Serilmez, T. Karkas, E. B. Celem and S. Onal. 2011. Immobilization and stabilization of $\alpha$-galactosidase on Sepabeads EC-EA and EC-HA. Int. J. Biol. Macromol. 49:855-860

Bora, U., K. Kannan and P. Nahar. 2005. A simple method for functionalization of cellulose membrane for covalent immobilization of biomolecules. J. Membr. Sci. 250:215-222.

Celem, E. B. and S. Onal. 2009. Immobilization of phytase on epoxy-activated Sepabead EC-EP for the hydrolysis of soymilk phytate. J. Mol. Cat. B: Enzym. 61:150-156.

Cong, L., R. Kaul, U. Dissing and B. Mattiasson. 1995. A model study on Eudragit and polyethyleneimine as soluble carriers of $\alpha$-amylase for repeated hydrolysis of starch. J. Biotechnol. 42:75-84.

De Lumen, O. B. 1992. Molecular strategies to improve protein quality and reduce flatulence in legumes. Food Struct. 11:3346.

Falkoski, D. L., V. M. Guimaraes, M. V. de Queiroz, E. F. de Araujo, M. N. de Almeida, E. G. de Barros and S. T. de Rezende. 2009. Covalent immobilization of $\alpha$-galactosidase from Penicillium griseoroseum and its application in oligosaccharides hydrolysis. Appl. Biochem. Biotechnol. 158:540-551.

Francesch, M. and A. M. Perez-Vendrell. 1997. Recent studies on enzyme application in animal feeding. Cahiers Options Mediterraneennes. 26:149-159.

Gaur, R., Lata and S. K. Khare. 2005. Immobilization of xylandegrading enzymes from Scytalidium thermophilum on Eudragit L-100. World J. Microbiol. Biotechnol. 21:1123-1128.

Ghazi, S., J. A. Rooke and H. Galbraith. 2003. Improvement of the nutritive value of soybean meal by protease and $\alpha$ galactosidase treatment in broiler cockerels and broiler chicks. Br. Poult. Sci. 44:410-418.

Gote, M., H. Umalkar, I. Khan and J. Khire. 2004. Thermostable $\alpha$-galactosidase from Bacillus stearothermophilus and its application in the removal of flatulence causing from soymilk. Process Biochem. 39:1723-1729.

Karr-Lilienthal, L. K., C. T. Kadzere, C. M. Grieshop and G. C. Fahey Jr. 2005. Chemical and nutritional properties of soybean carbohydrates as related to nonruminants: A review. Livest. Prod. Sci. 97:1-12.

Lee, J., I. Park and J. Cho. 2012. Production and partial characterization of $\alpha$-galactosidase activity from an Antarctic bacterial isolate, Bacillus LX-1. Afr. J. Biotechnol. 11:1239612405.

Monica, D., T. Vintila, V. O. Beatrice and P. Gabriela. 2008. Stabilization of microbial enzymatic preparations used in feed industry. Lucrari stiintifice Zootehnie si Biotehnologii 41:6972 .

Naumov, D. G. 2004. Phylogenetic analysis of $\alpha$-galactosidases of the GH27 family. Mol Biol. (Mosk). 38:463-476.

Okutucu, B., E. B. Celem and S. Onal. 2010. Immobilization of $\alpha$ galactosidase on galactose-containing polymeric beads. Enzyme Microb. Technol. 46:200-205.

Onal, S. and A. Telefoncu. 2003a. Comparison of chitin and Amberlite IRA-938 for alpha-galactosidase immobilization. Artif Cells Blood Substit. Immobil. Biotechnol. 31:19-33.

Onal, S. and A. Telefoncu. 2003b. Preparation and properties of $\alpha$ galactosidase chemically attached to activated chitin. Artif Cells Blood Substit. Immobil. Biotechnol. 31:339-355.

Prashanth, S. J. and V. H. Mulimani. 2005. Soymilk oligosaccharide hydrolysis by Aspergillus oryzae $\alpha$ galactosidase immobilized in calcium alginate. Process Biochem. 40:1199-1205.

Roy, I., A. Gupta, S. K. Khare, V. S. Bisaria and M. N. Gupta. 2003. Immobilization of xylan-degrading enzymes from Melanocarpus albomyces IIS 68 on the smart polymer Eudragit L-100. Appl. Microbiol. Biotechnol. 61:309-313.

Sanjay, G. and S. Sugunan. 2005. Immobilization of $\alpha$-amylase onto K-10 montmorillonite: characterization and comparison of activity in a batch and a fixed-bed reactor. Clay Minerals. 40:499-510.

Sardar, M., I. Roy and M. Gupta. 2000. Simultaneous purification and immobilization of Aspergillus niger xylanase on the reversibly soluble polymer Eudragit ${ }^{\mathrm{TM}} \mathrm{L}-100$. Enzyme Microb. Technol. 27:672-679.

Schasteen, C. S., J. Wu, M. G. Schulz and C. M. Parsons. 2007. Correlation of an immobilized digestive enzyme assay with poultry true amino acid digestibility for soybean meal. Poult. Sci. 86:343-348.

Sharma, S., P. Kaur, A. Jain, M. R. Rajeswari and M. N. Gupta. 2003. A smart bioconjugate of chymotrypsin. Biomacromolecules 4:330-336.

Silva, C. J. S. M., Q. Zhang, J. Shen and A. Cavaco-Paulo. 2006. Immobilization of proteases with a water soluble-insoluble reversible polymer for treatment of wool. Enzyme Microb. Technol. 39:634-640.

Steggerda, F. R., E. A. Richard and J. J. Rackis. 1966. Effect of various soybean products on flatulence in the adult man. Proc. Soc. Exp. Biol. Med. 121:1235-1239.

Stein, H. H., L. L. Berger, J. K. Drackley, G. C. Fahey Jr, D. C. Hernot and C. M. Parsons. 2008. Nutritional properties and feeding values of soybeans and their coproducts. In: Soybeans, Chemistry, Production, Processing, and Utilization (Ed. A. Johnson, P. J. White and R. Galloway). AOCS Press, Urbana, IL, USA. pp. 613-660.

Suarez, F. L., J. Springfield, J. K. Furne, T. T. Lohrmann, P. S. Kerr and M. D. Levitt. 1999. Gas production in humans ingesting a soybean meal derived from beans naturally low in oligosaccharides. Am. J. Clin. Nutr. 69:135-139.

Sulabo, R. C., C. K. Jones, M. D. Tokach, R. D. Goodband, S. S. Dritz, D. R. Campbell, B. W. Ratliff, J. M. DeRouchey and J. L. Nelssen. 2011. Factors affecting storage stability of various commercial phytase sources. J. Anim. Sci. 89:4262-4271.

Thippeswamy, S. and V. H. Mulimani. 2002. Enzymatic degradation of raffinose family oligosaccharides in soymilk by 
immobilized $\alpha$-galactosidase from Gibberella fujikuroi. Vila, B. and J. Mascarell. 1999. $\alpha$-Galactosides in soybean meal: Process Biochem. 38:635-640. can enzyme help. Feed Inter. 6:24-29.

Venkatesh, D. N., A. K. Reddy, M. K. Samanta and B. Suresh. 2009. Development and in vitro evaluation of colonic drug delivery systems for tegaserod maleate. Asian J. Pharmaceutics. 3:50-53.

Zhang, Y., J. Xu, Z. Yuan, H. Xu and Q. Yu. 2010. Artificial neural network-genetic algorithm based optimization for the immobilization of cellulase on the smart polymer Eudragit L100. Bioresour. Technol. 101:3153-3158. 